\title{
İlk Okuma Yazma Öğrenmede Çocukların Yaşadıkları Güçlükler, Nedenleri ve Çözüm Önerileri: Nitel Bir Araştırma
}

\author{
Aysel Ferah ÖZCAN*, Ali Osman ÖZCAN**
}

Öz

$\mathrm{Bu}$ araştırma, ilk okuma ve yazma öğretiminde çocukların yaşadıkları problemleri ve çözümlerini belirlemek amacıyla yapılmıştır. Araştırma nitel/olgu bilim araştırma deseninde planlanıp 20 ilkokul birinci sınıf öğretmeninin katılımıyla gerçekleştirilmiştir. Araştırma bulguları dil birimleri, çocuk, program ve aile ile ilgili verilerin çözümlenmesine yöneliktir. Sonuç olarak ilk okuma yazma öğrenmede çocukların dil birimlerinin algılanmasına yönelik problemlerle, aile ve programdan kaynaklanan güçlüklerinin olduğu görülmüștür. Öğretmenler, birinci sınıf öğrencilerinin ilk okuma yazma öğrenirken benzer sesleri hem okumada hem diktede karıştırdıklarını belirtmişlerdir. Okumada yazılışı benzer harfler (b-d, n-m vb.), diktede ise işitilebilirliği düşük ve söylenişi benzer olan sesler (n-l, s-z, ğ vb.) birbirine karıştırılmaktadır. Öğretmenlere göre, ilk okuma yazma öğrenirken çocukların en çok zorlandıkları süreç açı heceleri okuma ve yazma ile harf çatma sürecidir. Araştırma sonucunda ilk okuma yazma öğretiminde harf-ses sırasının gözden geçirilmesi, birinci sınıfa başlayacak çocukların hazırbulunuşluk düzeylerinin belirlenmesi vb. önerilerde bulunulmuştur.

Anahtar Kelimeler: İlk Okuma-Yazma, Dil Birimleri, Görme ve Ses AlgıSı, Eğitim Programları.

DOI: http://dx.doi.org/10.17336/igusbd.61470

* Okutman, Sakarya Üniversitesi Eğitim Fakültesi, E-posta: ayselferah@yahoo.com

** Prof. Dr., İstanbul Gelişim Üniversitesi, İISBF, Psikoloji Bölümü Öğretim Üyesi,

E-posta: aliosmanozcan@yahoo.com 


\section{Initial Reading and Writing Difficulties in Learning that Children's Lives, Causes and Solutions: A Qualitative Study}

Sayfa/Page | 70 İGÜSBD Cilt: 3 Sayı: 1 Nisan / April 2016

\section{Abstract}

This research was carried out in the initial reading and writing instruction in order to determine problems and solutions faced by children. The research is planned within the pattern of qualitative/science and was conducted with the participation of 20 first-class primary school teachers as patients. The findings reflect on the analysis of the data on language units, child, program and family. As a result, it is detected that the problems on the perception of childrens' language units in initial reading and writing are related to the difficulties arising from family and program. The most difficult process at initial learning to read and write is children's letter-sound collision process. Teachers stated that first grade students confuse similar sounds both at reading and dictating while learning initial literacy. At reading, similarly written letters (b-d, n-m, and etc.) and at dictation, similarly pronounced sounds with low audibility (n-l, s-z, ğ, and etc.) are confused with each other. According to the teachers, the most challenging process for students is to read open syllables and to join letters. As a result of the study, it is suggested to review the letter- sound order at initial literacy teaching, and to determine the readiness level for children to be first graders.

Keywords: Initial Reading-Writing, Language Units, Visual and Sound Perception, Educational Programs.

\section{Giriş}

Çocuklar ilkokul öncesi dönemde, ses bilgisel beceriler, alfabe bilgisi, yazı kavramı ve sözlü dil becerileri gibi becerileri kazanırlar. İlk okuma yazma öğretimi ile beraber çocuk, o güne kadar öğrendiği dilin sözlü kodlarını çözmeyi ve bu kodları görsel kodlarla birleștirmeyi öğrenmek durumundadır. "İlk okuma-yazma etkinliği; Türk alfabesindeki harflerin birbirleriyle ilişkilerini tanıyarak, harflerin bağlı bulunduğu dille ilgili birimleri yazı içinde ayırt ederek, yazılı metnin içeriğini kavrama olarak tanımlanabilir"1. Dolayısıyla ilk okuma yazmada yazılı ve sözlü dilin işaretlerine yönelik görsel farkındalık ve ses farkındalığı son derece önemli iki alan olarak kabul edilebilir.

${ }^{1}$ Ali Osman Özcan \& Aysel Ferah Özcan, "Türk Çocuklarının Ses Gelişim Özellikleri ve İlk Okuma Yazma Öğrenme", İstanbul Gelişim Üniversitesi Sosyal Bilimler Dergisi, 1 (2), 2014, s. 67. 
İlk okuma yazma öğrenmeye başlama ve ilk okuma yazmayı beceri haline getirme özdeș değildir. İlk okuma yazma öğrenmeye başlama görselmotor koordinasyon, ses algısı, bellek süreçleri, duygusal ve bedensel işlevlerin olgunlaşması ve gelişimine bağlıdır. İlk okuma yazma becerisi ise görsel ve işitsel alanın bütünleștirilerek pekiştirilmesini gerektirmektedir. $\mathrm{Bu}$ makalede ilk okuma yazmada dil birimsel farkındalık ve gelişimi ele alındıktan sonra öğrenme esnasında çocukların karşılaştıkları güçlükler, nedenleri ve çözüm önerileri değerlendirilmeye çalışılmıştır.

\section{İlk Okuma Yazmada Ses Bilgisel ve Yazı Bilgisel Gelişim}

İlk okuma yazmada her bir sesin algılanması ve seslerin görsel simgeleri olan harflerle ilişkilerinin kurulması öğretimin temel ilkelerinden biridir. "Çocuğun seslerin işaretlerini sıraya koyma, düzenleme, birleștirme, ayırma ve kendi aralarındaki ilişkileri kurarken ortaya koyduğu yapılar, onun zihin ile ilgili işlemlerini yansıtır. İlk okuma-yazmayı öğrenirken alfabeyi oluşturan işaretler arası ilişkileri kurup harflerin-seslerin işlevleriyle zihin ile ilgili işlemlerini doğru bir şekilde yapmak zorundadır."2. "Fonomik farkındalık, konuşulan kelimelerdeki her sesi duyabilme becerisi ve konuşmaların bu seslerden oluştuğunu anlamadır... Alfabe bilgisi ise, harflerin farklı şekillerinin ve her birinin özel bir sesle ilgili olduğu anlayışıdır³. Çocuklar tek tek harfleri seslendirmek kadar, hece-kelime grupları içinde de sesleri tanıyıp eşleştirip çözümlemek zorundadırlar.

Alan yazında ses algısı kavramının ses bilgisel farkındalık olarak kavramlaştırıldığı görülmektedir. "Ses bilgisel farkındalık, İngilizce gibi alfabetik dillerde okumayı öğrenmek için kritik bir öneme sahiptir"4. Ses bilgisel işleme yeteneği beş alt faktörle ilişkili olarak açıklanmaktadır. "Bunlar: Ses bilgisel çözümleme, ses bilgisel bütünleştirme (birleşim), çalışma belleğinde ses bilgisel kodlama, isimleri soyutlama ve isimleri serileme vb. yeteneklerdir. $\mathrm{Bu}$ yeteneklerin gelişiminde, bireysel farklılıklar görülmektedir"5. Örneğin "Harf adı bilen çocuklar, harfleri dikte ve kopya etmede daha başarılıdırlar. Harfleri yazma becerileri ile kopya veya dikte

${ }^{2}$ Ali Osman Özcan \& Aysel Ferah Özcan, a.g.m., 69.

3 Jeffret Trawick-Swith, Erken Çocukluk Döneminde Gelişim, (çev. ed. Berrin Akman). Ankara: Nobel Yayınları, 2013, s.286-287.

${ }^{4}$ Anthony Jason. L. \& , Development of Phonological Awareness. Current Directions in Psychological Science. 14 (5), 2005, s.255.

${ }^{5}$ Richard, K. Wagner... vd., "Development of Reading-Related Phonological Processing Abilities: New Evidence of Bidirectional Causality From A Latent Variable Longitudinal Study", Developmental Psychology, 30 (1), 1994, s.73.

Sayfa/Page | 71

İGÜSBD

Cilt: 3 Sayı: 1

Nisan /

April 2016 
yoluyla sayıları yazma becerileri de ilişkilidir. Araştırmalar da, ses bilgisel bilgi işlemenin kelime çözümlemeyi öğrenmede güçlü bir nedensel etken olduğu, ancak harf adı bilgisinin göreceli bir etkiye sahip olduğunu ortaya koymaktadır". 6

Sayfa/Page | 72 İGÜSBD Cilt: 3 Sayı: 1 Nisan / April 2016

\section{Sesleri Algılamanın Etkileri}

Ses algısının artışında yaş önemli bir faktördür. "Çocukların yaşı arttıkça farklı düzeylerdeki dilsel karmaşıklıkta (örneğin heceler ve sesler) ses bilgisel duyarlılıkları hem mutlak olarak artmakta hem de daha kararlı hale gelmektedir".7 İngilizce gibi fonolojik olmayan dillerde ses birleşimlerinin algılanması okul yıllarına kadar gelişime devam edebilmektedir. "Bazı ünsüz sesler ve karışımları oldukça zordur. Bu seslerin en iyi şekilde çıkarılması 7-8 yaşına kadar sürebilir" 8 . Araştırmalar ses bilgisel farkındalığın eğitimle artırılabileceğini göstermektedir. "Birinci sınıfın sonunda, iki yıllık eğitime alınan çocuklar; ses bilgisi, harf adı, ses bilgisel farkındalığın ölçümünde ve hecelemede, sözcük tanıma ile ilgili ölçümlerde de diğer çocuklardan daha yüksek puan almışlar ve doğru yazmaları için fonetik destek verildiğinde yazmada da daha başarılı olmuşlardır". ${ }^{9}$ "Ses bilgisel farkındalık önemli olmakla beraber erken okuma için yeterli bir koşul değildir".10 Erken okumanın ses bilgisel farkındalık dışında ilişsili olduğu pek çok değişken bulunmaktadır.

Araştırmalar okuma yazma öğrenmede ses bilgisel bozukluğu olan çocukların ciddi bir başarısızlık riski ile karşı karşıya olduklarını ortaya koymaktadır. "Ses bilgisel bozukluğu olan çocukların çoğu harf seslerini bilmesine rağmen, gerçek sözcüklerin yanı sıra sözcük olmayanları yazma ve okumada da başarısızdırlar. Hem okuma-yazma problemleri hem konuşma bozukluklarının heceleri küçük ses bilgisel birimlere (fonemler) ayırmadaki

${ }^{6}$ S.. Graham... vd., "Dimensions of Good and Poor Handwriting Legibility in First and Second Graders: Motor Programs, Visual-Spatial Arrangement, and Letter Formation Parameter Setting", Developmental Neuropsychology. Vol 29(1), 2010, s.43.

${ }^{7}$ Christopher. J. Lonigan... vd., Development of phonological sensitivity in 2- to 5-yearold children. Journal of Educational Psychology, 90(2), 1998, s.294.

8 Jeffret Trawick-Swith, a.g.e., s.269.

9 Benita, A. Blachman... vd., "Developing Phonological Awareness and Word Recognition Skills: A Two-Year Intervention With Low-Income, Inner-City Children", Reading and Writing. 11 (3), 1999, s.239.

${ }^{10}$ Adriane, G. Bus... vd.,Phonological awareness and early reading: A meta-analysis of experimental training studies. Journal of Educational Psychology, 91 (3), 1999, s.403. 
başarısızlıktan ortaya çıktığı ileri sürülebilir".11 Okuma-yazma öğrenmede önemli bir aşama olan heceleri seslerine ayırma aşamasındaki başarısızlık okuma-yazma güçlükleri olarak karşımıza çıkmaktadır.

\section{İlk Yazmada Görsel Farkındalık ve Yazma Becerileri}

İlk okuma yazmada sesler kadar onların grafik simgeleri olan harfler de önemlidir. "Okula yeni başlayan çocuk, sağ elle yazmayı, her satırı soldan sağa takip etmeyi, harfleri soldan sağa hesap etmeyi öğrenmek zorundadır. Kısaca dik bir düzlemden yatay bir düzleme harfleri aktarma iktidarını kazanmış olmalıdır. Bunu başaramadığı zaman, aynadaki yazı gibi yazar. Nesnelerin şekil, büyüklük, renk ve mekândaki durumlarını gözüyle kestirip tahmini bir şekilde yazmak zorunda olduğundan, buradaki başarısızlığı ortaya koyduğu yazıya da yansımaktadır"12. Bu aşamalar yazma ile ilgili aşamalardır ve görme alanıyla ilişkilidirler. Araştırmalar çocukların harfleri ve rakamları ayna yazısına dönüştürerek yazma eğilimlerinin sayı ve harf çiftleriyle ilgili beceri eksikliği ve dikkat sürelerinin kısalığından kaynaklandığını, akademik başarılarının da düşük olacağını göstermektedir.13

“Doğru yazmanın belirleyicilerini yedi aşamada ele alınabilir. Bunlar;

- Yazma esnasında, harflerin uzun-kısa, yukarı-aşağı doğru oluşları vb. görme ile ilgili depolanmış özellikleri hatırlanır,

- Depolanmış yazmanın motoriği özelliklerini hatırlanır (boy-y nin öğrenilmesi)ve harf-ses bağlantısı kurulur.

- Bellekten görme motoriği ile ilgili bilgiler çağrılır,

- Sözcüklerin şekil bakımından yapısını kavrar (Cümle ilişkilerinde sözcük șekil yapısını kavrama -el ele-). kavrama),

- İmla kurallarına dikkat etme (doğru yazma kuralları, işaret gruplarını

- Ses-harf seviyesinde sözcükleri kavrama (ses-harf ilişkileri, seslerin birbirini takibi),

- Anlamı kavrama ve duygusal muhtevayı hissetme.

\footnotetext{
${ }^{11} \mathrm{~J}$. Bird... vd., "Phonological Awareness and Literacy Development in Children With Expressive Phonological Impairments", Journal of Speech, Language, and Hearing Research, 38, 1995, s.446.

12 Ali Osman Özcan, "ilk Okuma Yazma Öğretim Programlarının Geliştirilmesi", Hacettepe Üniversitesi Eğitim Bilimleri Dergisi: 8, 1992, s.176-177.

${ }_{13}$ M. L. Simmer, Printing Erors in Kindergarten and the Prediction of Akademic Performance. Journal of Learning Disabilities. 15(1), 1982, s.159.
} 
Sayfa/Page | 74 İGÜSBD Cilt: 3 Sayı: 1 Nisan / April 2016

Yazmayı öğrenme birden fazla öğrenme alanını içeren eşgüdümlü bir eylemdir".14 "Görsel algı becerileri, çocukların okuma, yazma, heceleme, matematik yeteneklerini geliştirmekte ve okulda başarılı olmaları için gerekli diğer yeteneklerinin tümünü artırmalarına yardımcı olmaktadır". ${ }^{15}$

\section{Çocuklarda Hece, Sözcük, Cümle Gibi Dil Birimlerinin Farkındalığı ve İlk Okuma Yazma}

İlk okuma yazma hece, sözcük ve cümle gibi dil birimlerinin çözümlenmesi ve bütünleştirilmesi ile kazanılan bir beceridir. "Cümle, sözcük ve hece gibi dil birimlerinin karşılaştırılması, ayırt edilebilmesi ilk okuma yazma mekanizmasını kavrayabilmek için gereklidir". ${ }^{16}$ Bu karşılaştırmada karşımıza en önemli bileşen olarak yine ses algısı çıkmaktadır. Çocukların yazılı dilin seslerini çözümlemelerinde konuşulan dilin yapısal etkileri de söz konusudur. Bu yapıları çocukların kavrayıp uygulayabilmeleri gerekir.

Araştırmalar hece, sözcük, cümle gibi dil birimlerin farkındalığının ses algısının gelişimi ve dilin yapısıyla olan ilişkilerine vurgu yapmaktadır. "Çek çocukları İngiliz çocuklarına oranla hem yazma hem ses bilgisel farkındalık becerilerinde daha başarılıdırlar. Çünkü Çekçe hem yazılı dil (ortografik yapılar) hem sözlü dil (hece yapıları) bakımından İngilizceden oldukça karmaşıktır. Sonuç olarak ses bilgisel farkındalığın erken gelişiminin ses bilgisel girdiden ve yazının doğasından etkilendiği ve bu durumun okuryazarlık becerilerine katkı sağladığı ileri sürülebilir". ${ }^{17}$

İlkokul çocuklarının yazılı sözcüklerdeki hece birimlerini nasıl algıladıklarına yönelik olarak yapılan çalışmalar, ilk okuma yazma öğrenmede hece çözümlemenin önemli bir süreç olduğunu ortaya koymaktadır. Bir araştırma "İlk okuma yazma sürecinin ilk yıllarının sonuna varır varmaz çocukların yazı dizileri içindeki heceleri algıladıklarını göstermiştir. $\mathrm{Bu}$ birimlerin algısı iki bilgi kaynağının sonucudur: Hece ses bilgisi ve okunan (algılanan) harf fazlalı̆̆ı. Hece, okumayı öğrenme sürecinde ilgili bir birim

${ }^{14}$ Ali Osman Özcan, "ïlk Okuma Yazma Döneminde Yazma Becerisini Öğrenme”, Marmara Üniversitesi Atatürk Eğitim Fakültesi Eğitim Bilimleri Dergisi. 3, 1991, s.204206.

15 Marianne Frostig, Pictures and Patterns: Teacher's Guide, Palo Alto, CA, Consulting Psychologists Press, 1968.

${ }^{16}$ Aysel Ferah, Türkçe İlk Okuma ve Yazmayı Öğrenme, Türkçe Okuyup Yazmak İçin, Ankara: Nobel Yayınları, 2007, s.103.

17 Marketa Caravolas \& Maggie Bruck, "The Effect of Oral and Written Language Input on Children's Phonological Awareness: A Cross-Linguistic Study", Journal of

Experimental Child Psychology. 55, 1993, s. 1. 
olabilir". ${ }^{18}$ Hece çözümleme süreci harf-hece bilgisi arttıkça başarılı bir şekilde gerçekleştirilmektedir.

Araştırmalar çocukların sözcüklerin içindeki sesleri parçalama yeteneğinin okuma yazmayı öğrenme ile ilişkili olduğu bulgusuna vurgu yapmaktadır. Sonuç olarak "Çocukların sistematik ses bilgisel eğitimden yararlanma yeteneklerinin onların yazma gelişim düzeylerine bağlı olduğu ve birinci sınıfta ve okulöncesinde çocukları yazmaya cesaretlendirmek için konuşulan dilin sözcüklerinin ve diğer anlamlı birimlerinin analizini sağlamanın önemli olduğunu vurgulamışlardır.19 Bulgulardan sözcük farkındalığının ses çözümlenmesiyle geliştiği ortaya çıkmaktadır.

Çocukların sesleri tanıma becerilerinin seslerin kullanım sıklığından etkilenmesi gibi20, sözcük tanıma becerilerinin de sözcük sıklığı faktöründen etkilendiği görülmektedir. "İlkokul 1-5. sınıf çocuklarında sözcük tanıma üzerine yaptıkları çalışmada; çocukların sözel karar verme başarılarının sözcük sıklığından etkilendiği ve bu ilişkinin yaşın azalmasıyla arttığı; okuma yazma ediniminin ilk aşamalarında görsel tanıma üzerinde sözcük sıklığının güçlü bir etkisi olduğu; ortografik yakınlık yoğunluğu değişkeninin ise sözel karar verme yetisi üzerinde anlamlı bir etki yapmadığı sonucuna ulaşılmıştır".21

Çocuklar daha sık karşılaştıkları ve yaşantılarının bir parçası olan sözcükleri daha çabuk öğrenmektedirler. Sözcüklerin yazı bilgisel (ortografik=imlaya uygunluk) benzerliklerinin ise çocukların sözel karar verme becerilerini etkilemediği anlaşılmaktadır. Hatta çalışmalar yazı bilgisel benzerliğin çocukların öğrenme sürecine olumsuz etki ettiğini de ortaya koymaktadır. Bu sonuçtan hareketle ilk okuma yazma öğretiminde sözcüklerin yazı bilgisel benzerliklerinin değil kullanım sıklıklarının öğretimi kolaylaştırıcı olduğu söylenebilir. Bu açıdan sözcüklerin kullanım sıklığına dayalı bir öğretim gereklidir, denilebilir.

\footnotetext{
${ }^{18}$ Nage Doignon Zagar \& Daniel Zagar, "Do Children in The Process of Learning to Read Perceive the Syllable in Writing?", Canadian Journal of Experimental PsychologyRevue Canadienne de Psychologie Experimentale, 60 (4), 2006, s.258.

${ }^{19}$ A. Vernon Sofia \& Emilia Ferreiro, "Writing Development: A Neglected Variable in the Consideration of Phonological Awareness", Harvard Educational Review. 69 (4), 1999, s.395.

${ }^{20}$ Ali Osman Özcan ve Aysel Ferah Özcan, a.g.m., s. 81.

${ }^{21}$ Stéphane Dufau... vd., "A Developmantel Perspective on Visual Word Recognition: New Evidence and A Self-Organising Model", European Journal of Cognitive Psychology, 22 (5), 2010, s.690.
} 
Sayfa/Page | 76 İGÜSBD Cilt: 3 Sayı: 1 Nisan / April 2016

\section{İlk Okuma Yazmada Belleğin Rolü}

İlk okuma yazmada ses çözümlenmesinin yanı sıra bir dizi bellek işlem ve işlevi de işe karışmaktadır. "Ses bilgisel farkındalık, sözel kısa süreli hafızadan ziyade sözcük tanımanın bir belirleyicisidir."22. "Altı yaşındaki çocuklara uygulanan bellek eğitimi programı sonucunda, çocukların sözel ve görsel kısa süreli ve uzun süreli olmak üzere genel bellek indeksi, ertelenmiş tanıma ve öğrenme indeksi puanlarında anlamlı ölçüde artış olduğu $(\mathrm{p}<.001)$ bulunmuştur". ${ }^{23}$ Çocukların ilk okuma yazma dönemindeki bellekleri, bilinçli olarak geliştirilecek programların uygulanmasıyla daha da gelişme gösterebilir.

"Harf, hece, sözcük ve cümle gibi algı nesnesinin kapsamı, şekli ve içeriği yanında, okumaya yeni başlayan çocuğun algı nesnesini algılama süreci, yani zihni faaliyeti (düşünme) de önem taşımaktadır. Algılama süreci hiyerarşik bir şekilde yukarıdan aşağıya veya aşağıdan yukarıya (cümle - sözcük - hece harf veya tersi olabilir)". ${ }^{24}$ "Dikkat öğrenmenin gerekli bir önkoşuludur. Öğrenirken harfleri ayırt etmek için, çocuk farklı özellikleri öğrenir: b yi d den ayırt etmek için, öğrenciler yalnızca dikey çizgiye bitişik bir çizginin varlığına değil, dairenin sağ ve sol yanındaki dikey çizginin konumuna dikkat etmelidir. Öğretmenden öğrenmek için, öğrenciler öğretmenin sesine dikkat kesilmeli ve diğer sesleri duymazdan gelmelidir". 25

"Çocuk her bir harfi gördüğünde zamanla harflere yönelik dikkati azalır, otomatikleşir, "a" mıydı "b" miydi diye düşünmez. Harf gruplarının oluşturduğu anlam bağlamı önem kazanarak çocuğun muhakemesi de işe karışmaya başlar. Normal olarak çocuk, gelişim dönemi boyunca objelerin görsel izlerini belleğinde depolamakta ve bir üst zihinsel işlem yapabilmek için depolanan bellek içeriklerini kullanmaktadır". ${ }^{26}$

İlk okuma yazma öğrenilirken harf-ses, hece, sözcük ve cümlelerin hatırlanmasına ihtiyaç vardır. Hatırlama, öğrenilen içeriğe ait zihinsel

${ }^{22}$ K.L. Windfuhr \& M.J. Snowling, "The Relationship Between Paired Associate Learning and Phonological Skills in Normally Developing Readers", Journal of Experimental Child Psychology, 80 (2), 2001, s.160.

${ }^{23}$ A. Özyürek ve Esra Ömeroğlu, "Bellek Eğitimi Programının Altı Yaşındaki Çocukların Bellek Gelişimine Etkisinin İncelenmesi". Eğitim ve Bilim: 38 (168), 2013, s.30.

${ }^{24}$ Ali Osman Özcan, "İlk Okuma Yazma Öğretiminde Rol Oynayan Psikolojik Faktörler", Ankara: Hacettepe Üniversitesi II. Eğitim Bilimleri Sempozyumu Bildirileri, 1995, s. 3.

${ }^{25}$ D. H. Schunk, Öğrenme Teorileri, (çev: M. Y. Demir... vd.), Ankara. Nobel Yayıncllık, 2009, s.139.

${ }^{26}$ Aysel Ferah, "Eylem Boyutuyla İlk Okuma Yazma ve Ezberleme”, Milli Eğitim Dergisi. 149, 2001, s.23. 
imgelerin geri getirilmesi işlemidir. Bu esnada çocuk öğrendiklerini doğru sırada, ayrıntılı olarak hatırlayamayabilir. Hatırlamada muhakeme, karar verme işlemleri de rol oynadığından bazı çocuklardaki cümle, sözcük, hece ve harfleri yazarken ortaya çıkan kararsızlık davranışlarını birinci sınıf öğretmenleri açıç̧a gözleyebilirler.

\section{İlk Okuma Yazma Sürecine Aile ve Öğretmenin Etkisi}

Çocukların ilkokul birinci sınıftaki ilk okuma yazma başarılarında öğretmen-öğrenci iletişiminin şekli de etkilidir. "Yapılan çalışmalarda çocukların öğretmenlerle yakın iletişim kurduklarında okul başarı puanlarının attığı görülmektedir. Çocukların öğretmenlerle ilgili hisleri, çekişme ve yakınlıkla ilgili öğretmen algıları olarak belirlenen çocuk-öğretmen ilişkilerinin nitelikleri ile çocuğun okulöncesi ve birinci sınıf yazma başarısı ilişkilidir". ${ }^{27}$ Araştırmalar birinci sınıf öğrencilerinin okula hazırbulunuşluk düzeyini ailenin destekleyici, okulla işbirlikçi tutumlarının çocukların akademik başarılarını artırdığını ${ }^{28}$ vurgulamaktadır.

Bir çalışmada, "ailelerin çocukların yazma görevlerini tamamlamalarına yardım ettikleri zaman düşük düzeyde onlara yardımda bulundukları sonucuna ulaşılmıştır. Aileler çocuklara ince-motor ve kod çözme becerileri ile ilgili yazmada destek verirken çocukların yazma hatalarını düzeltmeye yönelik bir çaba göstermemişlerdir". ${ }^{29}$ Ancak çocukların yaptıkları yazma hatalarının anında düzeltilmesi, onların belleğe dil birimlerini hatalı kodlamalarının önüne geçeceğinden son derece önemli bir eylemdir.

\section{Araştırmanın Amacı}

İlk okuma yazma öğretimi uzun yıllardır üzerinde en çok tartışılan alanlardan biridir. İlk okuma yazmada yöntem sorunundan önce görme ve ses simgelerinin işlenmesinde ve belleğe alınmasında çocukların yaşadıkları temel güçlüklerin belirlenmesi, ilk okuma yazma öğretimine de katkıda bulunacaktır. İlk okuma yazma öğrenme aşamasında çocukların görme simgeleri, ses simgeleri ve dil birimlerini öğrenme sürecine yönelik sorunları ile çocuğun kendisinden, ailesinden ve programdan kaynaklı sorunların

\footnotetext{
${ }^{27}$ Kelley Mayer White, "Associations Between Teacher-Child Relationships and Children's Writing in Kindergarten and First Grade”, Early Childhood Research Quarterly 28, 2013, s.166.

28 Süleyman Çelenk, “Okul Başarısının Ön Koşulu: Okul Aile Dayanışması. Illköğretimonline, 2 (2), 2003, s.33.

${ }^{29}$ S.W. Bindman... vd., "Parental Writing Support and Preschoolers' Early Literacy, Language, and Fine Motor Skills", Early Childhood Research Quarterly 29, 2014, s.623.
}

Sayfa/Page | 77

İGÜSBD

Cilt: 3 Sayı: 1

Nisan /

April 2016 
belirlenip nedenlerinin ve çözüm önerilerin ortaya konması amaçlanmıştır. $\mathrm{Bu}$ amaçla araştırmada aşağıdaki sorular cevaplanmaya çalışılmıştır:

1. İlk okuma yazma öğrenme sürecinde ses alanıyla ile ilgili karşılaşılan problemler, nedenleri ve çözümlerine yönelik öğretmenlerin görüşleri nelerdir?

2. İlk okuma yazma öğrenme sürecinde görme örneği olarak harflerin öğretimiyle ilgili karşılaşllan problemler, nedenleri ve çözümüne yönelik sınıf öğretmenlerinin görüşleri nelerdir?

3. İlk okuma yazma öğrenme sürecinde dil birimlerini birleştirme ve çözümleme süreci ile ilgili karşılaşılan güçlükler ve nedenlerine yönelik sinıf öğretmenlerinin görüşleri nelerdir?

4. İlk okuma yazma öğrenme sürecinde çocuğun gelişimi ile ilgili karşılaşılan problemler, nedenleri ve çözümüne yönelik sınıf öğretmenlerinin görüşleri nelerdir?

5. İlk okuma yazma öğrenme sürecinde aileden ve eğitim programından kaynaklı problemler ve çözümüne yönelik sınıf öğretmenlerinin görüşleri nelerdir?

\section{Araştırmanın Önemi}

Çocukların görme ve ses sembollerinin işlenmesinde malzemeden ve çocuğun kendisinden kaynaklı sorunların belirlenmesi, öğretimin bu güçlüklerin ortadan kaldırılacak şekilde yeniden tasarlanmasına yol gösterici niteliktedir. İlk okuma yazmayı öğrenme sürecinde çocukların yaşadıkları güçlüklerin belirlenmesi, programın gözden geçirilip düzeltilmesi aşamasında katkı sağlaması bakımından önem taşımaktadır.

\section{Araştırmanın Modeli}

İlk okuma yazmayı öğrenme sürecinde çocukların karşılaştıkları güçlükleri, nedenlerini ve çözümlerini ortaya koymak amacıyla nitel bir araștırma deseni tasarlanmıștır. Nitel araştırmalar olay, olgu ve durumların olduğu gibi ortaya konmasını ve nedenlerinin belirlenmesini sağladığı gibi katılımcıların bizzat sürece dâhil olmalarını sağlaması bakımından da önemli bir araştırma desenidir. Araştırmada nitel araștırma yöntemlerinden amaca uygun olarak olgu bilim kullanılmıştır. "Fenomenoloji(olgu bilim), tümevarımsal tanımlayıcı bir araştırma yöntemidir. Burada amaç, tüm olgunun bireysel tecrübelerini de kapsayarak, göründüğü gibi tanımlanmasıdır. Bu yaklaşımda araștırmacı katılımcının öznel tecrübeleri ile ilgilenmekte, bireyin algılamaları ve olaylara yükledikleri anlamları 
incelemektedir". $30 \mathrm{Bu}$ amaçla ilk okuma yazma öğretiminde çocukların yaşadıkları güçlükler ve çözüm yollarını belirlemek için öğretmenlerin tecrübelerinden hareket edilmiştir. "Fenomenologların görevi, deneyimin yapısını ya da cevherini belirlemektir ${ }^{31 "}$.

\section{Araştırmanın Çalışma Grubu}

Araştırma 2014-2015 eğitim-öğretim döneminde İstanbul ili Beyoğlu, Kadıköy, Ataşehir ilçelerinden dört ilkokulda görev yapan toplam 14; Bursa İnegöl merkez ilçede görev yapan üç; Bilecik Bozüyük ilçesinde görev yapan üç olmak üzere toplam 20 sınıf öğretmeninin katılımıyla gerçekleştirilmiştir. "Fenomenolojide (olgu bilim) ilk elden ve sübjektif bir bilgi toplanması amaçlanmaktadır. Dolayısıyla örnekleme stratejisi amaçlı örneklemedir ve bu bağlamda tesadüfi olmayan örnekleme yapılmaktadır". $32 \mathrm{Bu}$ araştırmada amaçlı örnekleme uygun olarak ilkokul birinci sınıfları okutan öğretmenler örnekleme dâhil edilmiştir.

Tablo 1. Araştırmaya Katılan Birinci Sınıf Öğretmenleri İle İlgili Demografik Bilgiler

\begin{tabular}{|l|l|l|l|}
\hline Cinsiyet & F & $\begin{array}{l}\text { Kaçıncı Kez } \\
\text { Okuttuğu }\end{array}$ & F \\
\hline \multirow{2}{*}{ Kadın } & \multirow{2}{*}{17} & $1-3$ & 6 \\
\cline { 3 - 4 } & & $4-7$ & 11 \\
\hline \multirow{2}{*}{ Erkek } & \multirow{2}{*}{3} & $4-7$ & 2 \\
\cline { 3 - 4 } & & $8-10$ & 1 \\
\hline Toplam & 20 & & \\
\hline
\end{tabular}

Tablo 1 incelendiğinde örnekleme alınan öğretmenlerin 17'sinin bayan 32ünün erkek olduğu görülmektedir. Öğretmenlerin birinci sınıfları dörtten fazla okutanlarının sayısı 14'tür. Bu durum ilk okuma yazma öğretimi konusunda öğretmenlerin tecrübeli olduklarını göstermektedir.

30 Türker Baş ve Ulun Akturan, Nitel Araştırma Yöntemleri, Ankara: Seçkin Yayıncilık, 2008, s.84-85.

${ }^{31}$ Sharan B. Merrıam, Nitel Araştırma, (çev. ed. S. Turan), Ankara: Nobel Yayıncılık, 2013, s.25.

32 Türker Baş ve Ulun Akturan, a.g.e.. 2008, s.90.

Sayfa/Page | 79

İGÜSBD

Cilt: 3 Sayı: 1

Nisan /

April 2016 
Sayfa/Page | 80 İGÜSBD Cilt: 3 Sayı: 1 Nisan / April 2016

\section{Veri Toplama Aracı}

Araştırmada olgu bilim araştırma tasarımına uygun olarak yarı yapılandırılmış görüşme formu kullanılmıştır. İlkokul birinci sınıf öğrencilerinin ilk okuma yazma öğrenme sürecindeki problemlerini, nedenlerini ve çözüm önerilerini belirlemek üzere alanla ilgili sorular hazırlanmıștır. Yarı yapılandırılmış görüşme formunun hazırlanması esnasında alanyazın taranarak ilk okuma yazma öğrenme süreci ile ilgili temel kavramlar belirlenmiş, ilk okuma yazma öğrenme süreci ile ilgili temel kavramlara dayalı olarak soru formları geliştirilmiş, geliştirilen soru formları kıdemli bir birinci sınıf öğretmeni, alan uzmanı ve dilbilimci tarafından gözden geçirilip görüşleri alınarak son şekli verilmiştir.

Yarı yapılandırılmış görüşme formunun birinci bölümünde kişisel bilgiler, ikinci bölümünde ilk okuma yazmayı öğrenme sürecinde çocukların yaşadıkları problemler ile ilgili sorular, üçüncü bölümünde ilk okuma yazmayı öğrenme sürecinde çocukların yaşadıkları problemlerin nedenlerine yönelik sorular, dördüncü bölümünde ise ilk okuma yazmayı öğrenme sürecinde çocukların yaşadıkları problemlerin çözümüne yönelik görüşleri belirlemek üzere düzenlenen sorular yer almaktadır.

"Fenomenolojik (olgu bilim) araştırmada olgunun bireyin bakış açısından tanımlanmaya çalıșılması, tecrübelerin katılımcılar tarafından ayrıntılı bir şekilde yazılması ve bireyin olguya ilişkin davranışlarının gözlenmesi önemlidir". ${ }^{33}$ Araştırmadan elde edilen veriler içerik analizine tabi tutularak gerekli düzeltmeler yapılıp on adet birinci sınıf öğretmenine pilot uygulaması yapılmıştır. Anlaşılması güç olan sorular üzerinde gerekli düzeltmeler yapıldıktan sonra yarı yapılandırılmış görüşme formuna son şekli verilmiştir. Yarı yapılandırılmış görüşme formu on dört adet sorudan oluşmaktadır.

\section{Verilerin Analizi}

Araştırmadan elde edilen veriler içerik analizine tabi tutularak kodlanıp temalar elde edilmiştir. "Fenomenolojik araştırmada veri analizi dört aşamada gerçekleşir. Veri analizi tanımlama, belirleme, noetik ve neomatik ilişkilerin belirlenmesi ve esasların (özlerin) kuramsallaştırılması aşamalarını içerir". ${ }^{34}$ Araştırmada öğretmenlerle görüşme esnasında kayıt altına alınarak elde edilen veriler kodlanarak temalar oluşturulmuştur. Betimsel bir şekilde

33 Türker Baş ve Ulun Akturan, a.g.e., s. 91.

34 Türker Baş ve Ulun Akturan, a.g.e., s.92-93. 
ayrıntılar yorumlanmıștır. Araştırmanın güvenirliği, Miles ve Huberman'ın formülü kullanılarak hesaplanmıștır ("R" Güvenirlik = "Na"görüş birliği / "Na"görüş birliği + "Nd" görüş ayrılığı). Buna göre araştırmacılar arasındaki görüş birliği .95 olarak hesaplanmıştır [43: $(43+2) \times 100=.95]$. Bu sonuç, araştırmanın güvenilir olduğuna işaret etmektedir.

\section{Bulgular ve Yorum}

Bulgular iki ana başlık altında ele alınmıştır. Birincisi ilk okuma yazma öğretiminde karşılaşılan problemler ve nedenleri ikincisi de bu problemlerin çözümüne ilişkin öğretmen görüşlerini kapsamaktadır.

\section{Birinci Sınıf Öğretmenlerinin Görüşlerine Göre İlk Okuma Yazma Öğretiminde Karşılaşılan Güçlükler ve Nedenleri}

Bu bölümde ana temalar ve alt temalar çerçevesinde 2014-2015 Eğitim Öğretim yılında 1.sınıf okutmakta olan sınıf öğretmenlerinin ( $n=20)$ ilk okuma yazma öğrenmede karşılaşılan problemler ve bunların nedenlerine ilişkin görüşleri sunulmaktadır.

İlk okuma yazmada ilk harfleri yazma çalışmalarında öğrencilerin temel problemlerinin neler olduğunu belirlemek süreci doğru planlamak açısından önemlidir. Bu amaçla harf yazmaya başlarken karşılaşılan problemlere yönelik birinci sınıf öğretmenlerinin görüşleri aşağıda tablo 2'de verilmiştir.

Tablo 2. Harflerin yazımı sürecindeki problemler

\begin{tabular}{|l|l|l|}
\hline Tema & Alt Tema & F \\
\hline $\begin{array}{l}\text { Görme } \\
\text { Örneği } \\
\text { Olarak } \\
\text { Harfler }\end{array}$ & $\begin{array}{l}\text { Kalem tutamama ve satır } \\
\text { kavramına sahip olmama }\end{array}$ & 7 \\
\cline { 2 - 3 } & $\begin{array}{l}\text { Harflerin yönü ve } \\
\text { bağlantı zorlukları }\end{array}$ & 13 \\
\hline
\end{tabular}

Birinci sinıf öğretmenlerinin görüşlerine göre çocuklar ilk okuma yazma öğrenirken harflerin yazımı sürecinde kalem tutamama ve satır kavramına sahip olmama (7) ve harflerin yönü ve bağlantı güçlükleri $(n=13)$ nedeniyle öğrenme sürecinde zorlanmaktadırlar. Kalem tutamama küçük kas gelişimi ile ilgili bir beceri iken satır kavramına sahip olmama görsel algı ile ilgili bir beceridir. Harflerin yapıları ve çocukların görsel algı problemleri yazma öğrenme sürecine olumsuz etki yapmaktadır. $\mathrm{Bu}$ problemler bazı araştırmalarda da dile getirilmiştir. Bir araştırmada "İlkokul birinci sınıf öğrencilerinin göz-el koordinasyonu, mekân ilişkileri ve mekâna

Sayfa/Page | 81

İGÜSBD

Cilt: 3 Sayı: 1

Nisan /

April 2016 
yerleştirmede güçlük çektikleri oranda ilk okuma yazmada başarısız oldukları bulunmuştur". 35

Konu ile ilgili örnek görüşler aşağıda verilmiştir.

Ö1. "Bitişik eğik yazıya geçildikten sonra kılavuz çizgili defterlere

Sayfa/Page | 82 İGÜSBD Cilt: 3 Sayı: 1 Nisan April 2016 yazmak öğrenciler açısından güçlești. Çünkü çizgi aralıkları çoğaldı. Kalem tutmayı bilmiyorlar. Göz-motor koordinasyonu gelişmemiş. Öğrencilerin en büyük sorunu kalem tutma, harfi hangi aralığa yazacağını bilememe."

Ö15. "Harfleri yazmada kullanılan yönler birçok harfte sıkıntı oluşturuyor. Harflerin yazılış yönünü yanlış yapıyor. Örneğin D’yi yazarken geri dönmeyi birçok öğrenci unutuyor. Birbirine benzeyen harfler d ve b'nin verilme arası çok az, çok karıştırılıyorlar. Seslerin yazımında bağlantı noktalarının ve geri dönüşlerinin etkili olduğunu düşünüyorum. Çocuk sürekli geri dönüş yapmayı ve bağlanmayan seslerde ne yapacağını şaşırıyor. Harflerin mekân ilişkilerini ayırt edemiyorlar".

İlk okuma yazma sürecince çocukları harfleri yazmakta zorlanmaları nedenleri ilgili öğretmen görüşleri aşağıda tablo 3'de verilmiştir.

Tablo 3. Çocukların harfleri yazmada zorlanmalarının nedenleri

\begin{tabular}{|c|c|c|}
\hline Tema & Alt Tema & $\mathbf{F}$ \\
\hline \multirow{4}{*}{$\begin{array}{l}\text { Çocukların } \\
\text { Harfleri } \\
\text { Yazmada } \\
\text { Zorlanma } \\
\text { Nedenleri }\end{array}$} & $\begin{array}{l}\text { Hazırbulunuşluk düzeyi ve motor } \\
\text { gelişim }\end{array}$ & 9 \\
\hline & Motivasyon Eksikliği & 2 \\
\hline & $\begin{array}{l}\text { Bitişik eğik yazının çocuğa göre } \\
\text { olmayışı }\end{array}$ & 8 \\
\hline & $\begin{array}{l}\text { Harflerin ilk defa öğreniliyor } \\
\text { oluşu }\end{array}$ & 1 \\
\hline
\end{tabular}

Öğretmen görüşleri incelendiğinde ilk yazmayı öğrenme aşamasında çocuğun zorlanmasının nedenleri hazırbulunuşluk düzeyi ve motor gelişi eksikliği $(n=9)$, motivasyon eksikliği $(n=2)$, bitişik eğik yazının çocuğa göre olmayışı $(n=8)$ ve harflerin ilk defa öğreniliyor oluşu $(n=1)$ olarak belirtilmiștir.

35 Aysel Ferah, "İlk Okuma-Yazma Döneminde Görsel Algı ve Zekâ ile Okuma-Yazma Arasındaki Illişkilerin Araştırılması", IV. Ulusal Eğitim Bilimleri Kongresi, 1999, s.327341. 
Konu ile ilgili örnek görüşler aşağıda verilmiştir.

Ö13. "Ciddi bir dikkat eksikliği var. 0 da öğrenmeyi olumsuz yönde etkiliyor. Hazırbulunuşluk sorunları var. Küçük kaslarının yeterince gelişmemiş olması, yaşantı eksikliği, zihnen ve ruhen çocukların birinci sınıfta öğrenim görecek olgunlukta olmaması, sözcük hazinelerinin çok ama çok yetersiz olması, özellikle zamanı yanlış ifade etmeleri, yer ve yönü belirleyememeleri gibi çok büyük güçlüklerle karşı karşıya kalınıyor".

Ö6. "Bence en önemli güçlük motivasyon güçlügü. İstekli olan bir bireyin aşamayacağı engel yoktur.”.

Ö16. "Ses temelli okuma yazma öğretimi yönteminin getirisi olan bitişik eğik yazı çocukların kas anatomisine uygunluk göstermemektedir. Çocuklar dik çizgileri, eğik çizgilerden daha kolay yapabilmektedir. Bazı yuvarlak harf ve rakamların soldan sağa doğru yapılıyor olması çocuklar tarafından geç algılanmaktadır".

Ö1. "İlk harf yazımlarında o harfi hiç yazamayacaklarını düşünüyorlar ve gerçekten ilk grup harfler (E-L-A-T)'ın yazımı çok zor oluyor”.

İlk okuma yazma sürecince seslerin yapısal özelliklerinin ilk okuma yazma öğrenirken oluşturdukları problemlerle ilgili öğretmen görüşleri aşağıda tablo 4'te verilmiştir.

Tablo 4. Seslerin sesletim özelliklerinden kaynaklanan problemler

\begin{tabular}{|l|l|l|}
\hline Tema & Alt Tema & F \\
\hline Seslerin & Çocukların bazı sesleri çıaramaması & 18 \\
\cline { 2 - 3 } $\begin{array}{l}\text { Özletim } \\
\text { Özellikleri }\end{array}$ & $\begin{array}{l}\text { Cocukların sesleri hatırlamada } \\
\text { zorlanması }\end{array}$ & 2 \\
\hline
\end{tabular}

\section{Örnek:}

Ö14. "Öğrencilerin bir kısmı seslerin tamamını çıkartamadığı için "r" sesini "y" olarak çlkarıyorlar. Bu sebeple dikte esnasında da "arı" yazmak isteyen öğrenci "ayı" yazıyor".

Ö6. "Son grup seslerin çok fazla tekrarlanmaması ve Türkçe de yoğun olarak kullanılmamaları nedeniyle yazımı ve okunmasında hatırlanmama durumunun yaşanması".

Sayfa/Page | 83

İGÜSBD

Cilt: 3 Sayı: 1

Nisan /

April 2016 
Sayfa/Page | 84 İGÜSBD Cilt: 3 Sayı: 1 Nisan / April 2016

Öğretmen görüşleri incelendiğinde seslerin sesletim özelliklerinde kaynaklı problemler benzer seslerin ayırt edilememesi $(n=15)$, çocukların bazı sesleri çıkaramaması $(n=2)$ ve bazı seslerin günlük dilde az kullanılması $(n=2)$ olarak belirtildiği görülmektedir. Bazı sesleri çocuklar çıkarmakta zorlandıkları gibi, az kullanılan ve tekrarı yeterince yapılamayan sesleri de unutmaktadırlar.

İlk okuma yazma sürecince sesletim bakımından en çok karıştırılan seslerle ilgili öğretmen görüşleri aşağıda tablo 5 ve 6'da verilmiştir.

Tablo 5. Sesletim bakımından okumada en çok karıştırılan sesler

\begin{tabular}{|l|l|l|}
\hline Tema & Alt Tema & F \\
\hline $\begin{array}{l}\text { Okurken } \\
\text { Karıștırılan } \\
\text { Sesler }\end{array}$ & Benzer sesler okumada karıştırılıyor & 20 \\
("b" ve "d “, "n" ve "m") & \\
\hline
\end{tabular}

\section{Örnek:}

Ö1. "Harf yazmayı öğretirken birbirine yakın/benzer olan harfleri daha rahat kavrıyor ve yazıyor. Örneğin c-ç, b-d, g-ğ, n-m, s-ş, u-ü, o-ö, l-i vb... Yazı yazarken a sesi g ve ğ sesinin yazımına, $\mathrm{n}$ sesi de $\mathrm{h}$ sesinin yazımına temel oluşturuyor, kolaylaştırıyor. Ancak okuma esnasında bu benzerlik sorun oluşturuyor, gruplardaki sesler tam pekiştirilmeden verildiğinde bu sefer benzerlikler sorun oluşturuyor ve öğrenciler b’yi d ile, c'yi ç ile, n'yi m ile karıştırabiliyorlar. Sesletimde zorlandıkları harfler ise g, ğ, j, r, v, y şeklinde siralayabilirim".

Tablo 6. Sesletim bakımından diktede (yazmada) en çok karıştırılan sesler

\begin{tabular}{|l|l|l|}
\hline Tema & Alt Tema & F \\
\hline Diktede & Diktede sesletimi benzer ve ayırt & 20 \\
Karıştırılan & edilmesi zor olan sesler karıştırılıyor & \\
Sesler & ("n"ve "l","s" ve "z" ve "ğ"). & \\
\hline
\end{tabular}

\section{Örnek:}

Ö9. "Diktede birbirine benzeyen C - Ç, V - F, B - P vb. çoğunlukla yazarken karıștırılan harflerdir. Ğ ve $\mathrm{H}$ harfi ise yazıda unutuluyor. Örneğin 
öğretmen - öretmen, sağlık - salık, yağmur - yamur, havuç - avuç şeklinde yaziliyor".

Ö3. “Diktede, özellikle I ve y seslerini çlkarırken birbirine benzer sesler çıkardıkları için sesi kavrasalar bile ayırt etmekte güçlük yaşıyorlar. Aynı sıkıntıyı v-f seslerinde de yaşıyorlar".

Öğretmen görüşleri incelendiğinde sesletim bakımından hem okumada $(n=20)$ hem diktede $(n=20)$ en çok karıştırılan seslerin söyleyişi benzer ve işitsel ayırt edilirlikleri düşük olan sesler olduğu görülmektedir.

"Çocukların yanlış yazmalarında sadece grafik bakımdan değil, aynı zamanda metnin ses değişimleri, işitme ve görme hataları da görülür. Özellikle çocuklar aşağıdaki sesleri birbirine karıştırmakta ve bu sesleri çıkarmakta zorluk çekmektedirler. Bu sesler şunlardır: $\mathrm{P}-\mathrm{T}=$ =perde-terbe; yani rd, rb. yer değiştirtir. Ayrıca n-z=n-g= Tenzile engile, $g-c=$ Çalgl= çalcı; I-s: Davul=davus; $\mathrm{s}-\mathrm{t}=$ sabah-tabah, $\mathrm{t}-\mathrm{k}=$ bulut-buluk; I-b: balık-babık; g-c: güzel-cüzel; ş-k= başbak". 36

İlk okuma yazma sürecince çocukların sesleri öğrenme sürecinde zorlanma nedenlerine yönelik öğretmen görüşleri aşağıda tablo 7'de verilmiştir.

Tablo 7. Çocukların sesleri öğrenme esnasında zorlanmalarının nedenleri

\begin{tabular}{|l|l|l|}
\hline Tema & Alt Tema & f \\
\hline Çocukların & Seslerin çıkarılma güçlüğü & 7 \\
\cline { 2 - 3 } $\begin{array}{l}\text { Öğgrenmede } \\
\text { Zorlanma } \\
\text { Nedenleri }\end{array}$ & $\begin{array}{l}\text { Çocuğun bazı sesleri çıarabilecek } \\
\text { olgunlukta olmaması }\end{array}$ & 9 \\
\cline { 2 - 3 } & $\begin{array}{l}\text { Seslerin anlam ifade etmemesi ve } \\
\text { kullanım sıklığı }\end{array}$ & 3 \\
\cline { 2 - 3 } & Yöresel ağız ve ikinci dil & 1 \\
\hline
\end{tabular}

\section{Örnek:}

Ö10. “T, ğ, v, j harflerin sesletimi çocukları zorlamakta. Bu harflerin genellikle yanına $\mathrm{l}$, u gibi harfler ekleyerek söylüyorlar. Bu da yanlış öğrenmelere sebebiyet veriyor. T harfi 4. grupta öğretiliyor. Çocuklar Tı̆̆ diye

${ }^{36}$ Ali Osman Özcan, a.g.m., s.172-173.

Sayfa/Page | 85

İGÜSBD

Cilt: 3 Sayı: 1

Nisan /

April 2016 
seslendiriyorlar. Diğer sesli harflerle birleștirme yapamıyorlar. Bu durum seslerin kendi özelliklerinden kaynaklanıyor".

Ö17. "Konuşma bozukluğu olan öğrencilerin bazı sesleri

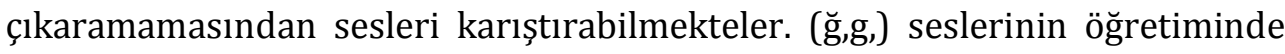
zorluk yaşanmaktadır".

Ö8. "Illk başta öğrenci o sesin ne olduğunu, nerede kullanacağını ve

karşısındaki büyügüunün neden sınıfta bebek uyutmaktan "ee ee" demekten bahsettiğini anlamıyor. Ve yanına bir kaç ses gelene kadar da bu sürüyor. Son grup seslerin çok fazla tekrarlanmaması ve Türkçe de yoğun olarak kullanılmamaları nedeniyle yazımı ve okunmasında hatırlanmama durumunun yaşanması sorun oluşturuyor".

Ö6. "Ben iki grup öğrenci profili gördüm. Birinci grup öğrenciler ailede farklı dil konuşulduğu için Türkçe ses-harf ve heceleri birleştirip okumakta zorlanıyorlardı. Oysa ikinci grup öğrenciler Türkçe 'ye büyük ölçüde hâkim oldukları için ses, hece ve sözcükleri ilk gördüklerinde çözdüler ve okudular".

Öğretmenler çocukların sesleri öğrenirken zorlanma nedenleri olarak seslerin yapısı $(n=7)$, çocuğun gelişimi $(n=9)$, seslerin anlam ifade etmemesini ve kullanım sıklığı $(n=3)$ ve yöresel ağız-ikinci dil $(n=1)$ belirtmişlerdir. Bulgular mevcut alanyazınla uygunluk göstermektedir. Bazı seslerin çocuklarda ediniminin sekiz yaşlarına kadar devam ettiği anlaşılmaktadır. Araştırmalarda Türk çocuklarının benzer sesleri okuma ve yazmada karıştırdıkları ve seslerin işitilebilirliklerinin güçlügüne dikkat çekilmektedir. "Örneğin k-t, g-d gibi önleştirme ve l-r gibi akıcıların farklılaştırılması veya f, v, $s, z, s$, j yerine $t, d, p, b$ gibi durak sesi üretme işlemleri yaşa bağlı olarak gelişmektedir. Ünsüzlerin yumuşaması yani ötümlüleşmesi hadisesi de (p, ç, t, k yerine b, c, d, g) yaşa bağlı gelișen işlemlerdir"37.

İlk okuma yazma sürecince karşılaşllan güçlüklerle ilgili öğretmen görüşleri aşağıda tablo 8'de verilmiştir.

${ }^{37}$ Ali Osman Özcan ve Aysel Ferah Özcan, a.g.m., s.76. 
Tablo 8. Harf-hece-sözcük-cümle-metin oluşturma bakımından karşılaşılan güçlükler

\begin{tabular}{|l|l|l|}
\hline Tema & Alt Tema & f \\
\hline $\begin{array}{l}\text { Süreç } \\
\text { İçindeki } \\
\text { Güçlükler }\end{array}$ & $\begin{array}{l}\text { Sesleri birleştirip hece } \\
\text { oluştururken açı } \\
\text { hecelerin zor kavranması } \\
\text { ve çok sesli hece okuma- } \\
\text { yazma güçlüğu. }\end{array}$ & 19 \\
\cline { 2 - 3 } & Cümle oluşturma & 1 \\
\hline
\end{tabular}

Sayfa/Page | 87

İGÜSBD

Cilt: 3 Sayı: 1

Nisan /

April 2016

\section{Örnek:}

Ö15. “Açık heceleri okumakta öğrenciler çok zorlanıyor ve uydurmalar yapıyorlar. En kolay süreç cümle oluşturma süreci oluyor. En zor süreç ise ses verme ve seslerden heceler oluşturmadır. Verilen harf-ses arttıkça öğrencilerimizin gittikçe artan düzeyde dikkatte, hatırlamada, yeniden üretmede fazlasıyla zorlandıklarını gözlemliyoruz. İkinci grup harfleri verdikten sonra diğer harflerin öğretimi için süre kısaldığı için sorunlar fazlalaşıyor, gerçekten bir keşmekeş yaşanıyor. Yani bazı öğrencilerde verilen harf-ses sayısı arttıkça kopma ve geri kalma mesafesi artıyor".

Ö1. "Öğrenciler el, al, at gibi tek hece ve kapalı heceden oluşan sözcükleri daha kolay öğrenirken açı heceleri ve açık heceli sözcükleri kapalı heceye göre daha zor öğreniyor, özellikle yazarken daha çok hata yapıyor. Ör: "anla" değil "anl" şeklinde; "elle" değil "ele" ; "anlat" değil "anlt" şeklinde yazım hataları yapılmaktadır. Birden çok heceli sözcükleri okurken zorlanıyorlar, hece sayısı arttıkça dikte yaparken zorlanıyorlar, aradaki ünlüleri unutabiliyorlar. Dağ, bağ gibi kapalı hecelere eklenen ünlü harf olduktan sonra (ör: dağ+a, bağ+a) o sözcüğü dağ-a ve bağ-a şeklinde heceledikleri görülmüştür".

Ö11. "Cümle kurmada güçlük yaşıyorlar. Özgün cümleler çıkmıyor ortaya. Bu sisteme göre anlamadan sadece okumayı öğreniyorlar”.

İlk okuma yazmada ez zor sürecin hece ve sözcük oluşturma süreci olduğu öğretmen görülerinden $(n=18)$ anlaşılmaktadır. Öğretmenlerden biri cümle oluşturma sürecinin zor olduğunu belirtmiștir. 
"Ses temelli cümle yaklaşımıyla ilk okuma yazma öğrenen öğrenciler kapalı heceye ses getirilerek oluşturulan sözcükleri yanlış hecelemekte ${ }^{38}$ ve açık heceye ulaşmada heceyi bölme problemi yaşamaktadırlar". ${ }^{39}$ İlk okuma yazma öğretiminde en zor süreç, harf-ses çatma ve açık heceyi öğrenme sürecidir.

Sayfa/Page | 88 İGÜSBD Cilt: 3 Sayı: 1 Nisan April 2016

İlk okuma yazma sürecince çocuktan kaynaklanan problemlerle ilgili öğretmen görüşleri aşağıda tablo 9'da verilmiştir.

Tablo 9. İlk okuma yazmada çocuktan kaynaklanan problemler

\begin{tabular}{|l|l|l|}
\hline Tema & Alt Tema & F \\
\hline $\begin{array}{l}\text { İlk Okuma } \\
\text { Yazmada } \\
\text { Çocuktan } \\
\text { Kaynaklı } \\
\text { Problemler }\end{array}$ & $\begin{array}{l}\text { Hazırbulunuşluk } \\
\text { eksikliği }\end{array}$ & 15 \\
\cline { 2 - 3 } & $\begin{array}{l}\text { Okulöncesi eğitim } \\
\text { almamış olması }\end{array}$ & 3 \\
\cline { 2 - 3 } & Yaşının küçüklüğü & 2 \\
\cline { 2 - 3 } & $\begin{array}{l}\text { Yazmayıp sevmeyip düz } \\
\text { yazı yazmak istemesi }\end{array}$ & 1 \\
\hline
\end{tabular}

\section{Örnek:}

Ö5. "Gelişim; bireysel farklılıkların etkisiyle 66 aylık her çocuk aynı seviyede olamaz. Bazı öğrenciler fiziksel olarak uygun yaşta olsa da bilişsel olarak hazır olmayabiliyorlar. Şu an okuttuğum sınıfta iki öğrencim bilişsel gelişim olarak 60 aylıklar. Hazırbulunuşlukları düşük.".

Ö19. "Okul öncesi eğitimi alması çocuğun motivasyonunu, algılamasını ve öğrenmesini kolaylaştırmaktadır".

Ö2. "Yaşı küçük çocuklar (isteğe bağlı gelenler) yazı ve okuma kısmında sıkıntı yaşıyorlar".

Ö12. "Genelde yazmayı sevmiyorlar, zorlanıyorlar. Düz yazı yazmak istiyorlar".

Öğretmenlerin büyük bir kısmı çocukların hazırbuluşlarının yetersiz olduğunu ( $n=15)$, bir kısmı okulöncesi eğitim alamamış olmasını $(n=3)$,

${ }^{38}$ Bahattin Acat ve Uğur Özsoy, "Ses Temelli Cümle Yöntemiyle İlk Okuma Yazma Öğretiminde Karşılaşılan Güçlükler", V. Ulusal Sinıf Öğretmenliği Kongresi, Gazi Üniversitesi, Ankara, 2006.

${ }^{39}$ Melek Gül Şahinel, a.g.m. 
yaşının küçük oluşunu (n=2) ve düz yazı yazmak istemesini $(n=1)$ ilk okuma yazma öğrenmede yaşanan problemlerin çocuktan kaynaklı nedenleri olarak belirtmişlerdir. İlk okuma yazma sürecince aileden kaynaklanan problemlerle ilgili öğretmen görüşleri așağıda tablo 10'da verilmiştir.

Tablo 10. İlk okuma yazma sürecinde aileden kaynaklanan problemler

\begin{tabular}{|l|l|l|}
\hline Tema & Alt Tema & f \\
\hline $\begin{array}{l}\text { Aileden } \\
\text { Kaynaklı }\end{array}$ & $\begin{array}{l}\text { Ailelerin eğitimsizliği, sistemi } \\
\text { bilmemesi. }\end{array}$ & 9 \\
\cline { 2 - 3 } & $\begin{array}{l}\text { Ailenin ilgisizlik ve } \\
\text { sorumsuzluğu }\end{array}$ & 11 \\
\hline
\end{tabular}

\section{Örnek:}

Ö1. “Ailelerin de çocukların eğitim sürecini desteklemesi gerek. Ama çoğu aile eğitimsiz ve çocuğa nasıl yaklaşacağını bilmiyor. Öğretim sistemini de bilmiyor. Bu durum da çocuğu olumsuz etkiliyor".

Ö3. "Aile evde yeteri kadar ilgilenmiyorsa ve sorumsuz davranıyorsa güçlükler yaşanıyor".

İlk okuma yazmada aileden kaynaklı problemlerle ilgili olarak öğretmenler ailenin eğitimsizliği $(n=9)$ ve ailenin ilgisizlik ve sorumsuzluğu $(\mathrm{n}=10)$ konularını belirtmişlerdir.

İlk okuma yazma sürecince programdan ve basılı materyalden kaynaklanan problemlerle ilgili öğretmen görüşleri aşağıda tablo 11 ve 12 'de verilmiştir.

Tablo 11. İlk okuma yazmada programdan kaynaklanan problemler

\begin{tabular}{|l|l|l|}
\hline Tema & Alt Tema & f \\
\hline Programdan & Bitişik eğik yazı ile öğretim & 10 \\
\cline { 2 - 3 } $\begin{array}{l}\text { Kaynaklanan } \\
\text { Güçlükler }\end{array}$ & Konuların işlevsizliği ve yoğunluğu & 3 \\
\cline { 2 - 3 } & $\begin{array}{l}\text { Yöntem nedeniyle okuyan ama } \\
\text { okuduğunu anlamayan öğrencilerin } \\
\text { oluşu. }\end{array}$ & 3 \\
\cline { 2 - 3 } & Öğrencinin gelişimine uygun değil & 4 \\
\hline
\end{tabular}


Sayfa/Page | 90 İGÜSBD Cilt: 3 Sayı: 1 Nisan / April 2016

\section{Örnek:}

Ö3. "El yazısı daha zor. Çocukların ilk okuma yazma öğrenmesinde karşılaşılan güçlük el yazısıdır. Program el yazısı ile başlamamalıydı".

Ö5. "Programın yoğunluğu bence en büyük güçlük. Aynı yıl içerisinde okuma yazma öğretiminin dışında verilmesi gereken kazanım sayısı çocukların alabileceğinden fazla. Bu yüzden kazanımlar için yeterli zaman ayıramıyorum ve yeterli etkinlik yapamıyorum.

Ö6. "Sözcük ve cümle yazımında öğrencinin anlamı üzerinde düşünmek yerine sadece duyduğunu yazmaya çalışması nedeniyle anlama kapasitesinin düşük gelişmesi. Sözcük ve cümle sayılarının fazla olmaması sebebiyle oluşturulan metinlerde sözcük veya cümlenin gereksiz ve sı tekrarları nedeniyle öğrenci anlamak yerine ezbere yöneltmesi".

Ö4. "Programın laboratuvar ortamı göz önüne alınarak yapılması, gerçek sınıf ortamından bihaber olması, bireysel farklılıkların göz ardı edilmesi, öğrenciden beklenenlerin çok yüksek tutulması".

Öğretmenler ilk okuma yazmada programdan kaynaklanan problemleri bitişik eğik yazı ile öğretim ( $n=10)$, konuların yoğun ve fazla oluşu $(n=3)$ ve yöntem nedeniyle okuyan ama okuduğunu anlayamayan öğrencilerin varlığı $(n=3)$, öğrencilerin gelişimine uygun olmayışı $(n=4)$ olarak ifade etmişlerdir. Sonuçlar, "öğrenciler bitişik eğik yazı yazarken zorlanmaktadırlar ${ }^{40 "}$ bulgusuyla örtüşmektedir.

Tablo 12. Illk okuma yazmada basılı materyalden kaynaklanan problemler

\begin{tabular}{|l|l|l|}
\hline & Alt Tema & F \\
\hline $\begin{array}{l}\text { Basılı } \\
\text { Materyalden } \\
\text { Kaynaklanan } \\
\text { Problemler }\end{array}$ & Kitapların öğretim sürecini desteklemekte & 20 \\
yetersiz oluşu. & \\
\hline
\end{tabular}

\section{Örnek:}

Ö4. "Ders kitapları çok yetersiz. Mutlaka yardımcı kitaplara ihtiyaç duyuyoruz. Bir sese sadece iki sayfa ayırıyor".

${ }^{40}$ Bahattin Acat ve Uğur Özsoy, a.g.m. 
Öğretmenler basılı malzemelerden kaynaklanan problemleri de kitapların öğretim sürecini desteklemekte yetersiz oluşu $(n=20)$ olarak belirtmişlerdir.

\section{Çözümlere Yönelik Öğretmen Görüşleri}

İlk okuma yazma sürecinde karşılaşılan güçlüklere yönelik çözüm önerileri geliştirilmesi, program yapıcılara yol gösterici olacaktır. Bu amaçla birinci sınıf öğretmenlerin ilk okuma yazmada karşılaştıkları güçlüklerin çözümüne yönelik görüşleri alınmış ve belirtilen çözümler sınıflanarak aşağıda tablolar halinde verilmiştir.

İlk okuma yazma sürecince harfi yazmayı öğrenme süreciyle ilgili çözümlere yönelik öğretmen görüşleri aşağıda tablo $13^{\prime}$ de verilmiştir.

Tablo 13. Harf öğretimi süreciyle ilgili çözümlere yönelik öğretmen görüşleri

\begin{tabular}{|l|l|l|}
\hline & Alt Tema & F \\
\hline $\begin{array}{l}\text { Harf } \\
\text { Öğretimine }\end{array}$ Yönelik & $\begin{array}{l}\text { Harflerin öğretim sırasını } \\
\text { değiştirme. }\end{array}$ & 2 \\
\cline { 2 - 3 } Çözümler & $\begin{array}{l}\text { İlk harflerin öğretimini } \\
\text { zamana yayma. }\end{array}$ & 13 \\
\cline { 2 - 3 } & $\begin{array}{l}\text { Havada, kum masasında ve } \\
\text { elinden tutarak yazdırma. }\end{array}$ & 4 \\
\cline { 2 - 3 } & Tekrara yer verme. & 3 \\
\hline
\end{tabular}

\section{Örnek:}

Ö1. "Sesli harfler dördüncü gruba kadar yayılmış durumda. Bence ilk iki grupta sesli harf sayısı arttırılsa daha çok hece ve sözcük olacağı için çocukların okuma hızı ve işin mantığını kavrama süreleri daha kısa olacaktır. Bunun yanında bence 'o' sesi ikinci grupta değil birinci grupta olmalı. Çocuğun hayatına okul denen şey girdi ve bu sesi daha kalıcı olarak buradan yola çıkarak öğretebiliriz. Nitekim ben öyle yaptım ve her gün geldikleri yer olan okulun 'o' sesiyle başladığını vurgulayarak bu sesi kolayca öğrettim. 'n-r' sesinin yazımında yaşanılan sıkıntılardan dolayı seslerin verilişleri birbirinden daha uzak olabilir. 'd-b' sesinin yazımlarının benzemesinden ve ' $v$ $\mathrm{f}^{\prime}$ seslerinin çıartılırken birbirlerine benzemesinden dolayı ses sıraları değiștirilebilir". 
Sayfa/Page | 92 İGÜSBD Cilt: 3 Sayı: 1 Nisan / April 2016

Ö3. "Illk okuma yazma öğrenme kısa sürede yapılmamalı bir yıla yayılmalıdır. Böylelikle her harf ve ses için gerekli öğretim süresi ayrılmış olur."

Ö5. "Benim gözlemlerime göre; çocuklar deftere yazma konusunda zorlanıyor. 0 yüzden önce kum havuzunda, havada, sonra tahtada, sonra kitaba ve en son da deftere yazdırıyorum. El kasları için ev çalışmaları (hamur vs.) veriyoruz. Fiziksel olarak hazır olmayan öğrencilerin kalem tutmada zorluk yaşaması durumunda kum havuzu oluşturuyorum ve orda sesin yazımını gerçekleștiriyoruz. Burada parmağıyla yazan öğrenci sonra havada yazıp ardından da kalem boyalarla yazabiliyor. Bu yazıları yazarken ilk grupta harfin yönünü takip etmekte zorlanıyorlar. Elinden tutarak en az bir satır yazdırıyorum".

Ö17. "Her hafta özel defterlerine tekrar amaçlı dikte çalışması yapılıyor, tarafımdan değerlendirilip veliye gönderiliyor. Tarih atıyorum ki gelişmeyi veya gerilemeyi görelim diye. Tekrar, okuma-yazma, ek çalışmalar ve teknoloji kullanma sık sık kullandığım yöntemler".

Öğretmenler harfi yazma sürecinde çözüm olarak harflerin öğretim sırasını değiştirme $(n=2)$, ilk harflerin öğretimini zamana yayma $(n=13)$, elinden tutarak yazma $(n=2)$ ve tekrara yer verme $(n=3)$ olarak belirtmişlerdir.

İlk okuma yazma sürecince ses öğretim sürecindeki çözümlerle ilgili öğretmen görüşleri aşağıda tablo 14'de verilmiştir.

Tablo 14. Ses öğretimi süreciyle ilgili çözümlere yönelik öğretmen görüşleri

\begin{tabular}{|l|l|l|}
\hline Tema & Alt Tema & F \\
\hline \multirow{2}{*}{$\begin{array}{l}\text { Ses öğretimi } \\
\text { süreciyle ilgili } \\
\text { çözümler }\end{array}$} & Teknolojiden yararlanma & 9 \\
\cline { 2 - 3 } & $\begin{array}{l}\text { Hikâye, masal ve } \\
\text { tekerlemelerden yararlanma }\end{array}$ & 4 \\
\cline { 2 - 3 } & Tekrara yer verme & 6 \\
\cline { 2 - 3 } & Seslerin sırasını değiştirme & 1 \\
\hline
\end{tabular}

\section{Örnek:}

Ö5. "Teknolojiden yararlanılarak seslerin kaynaklarını gösteriyorum. Çocuğun yaşamında kullandığı görsellerden yararlanılarak ses hissettiriliyor". 
Ö1. "Sesleri hikâye anlatmadan öğrettiğim zaman sorun yaşıyorum. Hikâyeyle, tekerlemeyle öğrendiğinde hafızasına yerleşiyor”.

Ö19. "Bol bol tekrar yapıp ek alıştırmalar veriyorum".

Ö3. "Mevcut ses veriliş sırasına uymuyorum. Yazılışı veya okunuşu birbirine benzer olan seslerin verilişinde araya farklı sesler veriyorum".

Ses öğretimi süreciyle ilgili olarak öğretmenler teknolojiden yararlanma $(n=9)$, hikâye-masal ve tekerlemelerden yararlanma $(n=4)$, tekrara yer verme $(n=6)$ ve seslerin sırasını değiştirme $(n=19)$ gibi çözüm yolları üretmektedirler.

İlk okuma yazma sürecince harf-hece-sözcük ve cümle öğretimindeki çözümlerle ilgili öğretmen görüşleri aşağıda tablo 15 'de verilmiştir.

Tablo 15. Harf-hece-sözcük ve cümle süreci ile ilgili çözümlere yönelik öğretmen görüşleri

\begin{tabular}{|l|l|l|}
\hline Tema & Alt Tema & F \\
\hline Harf-Hece- & Teknolojiden & 4 \\
Sözcük ve & $\begin{array}{l}\text { yararlanma } \\
\text { Cümle }\end{array}$ & \\
\cline { 2 - 3 } $\begin{array}{l}\text { Sürecine } \\
\text { Yönelik }\end{array}$ & Tekrar Alıştırmaları & 13 \\
\cline { 2 - 3 } Çözümler & kulış̧ma materyali & 3 \\
\hline
\end{tabular}

\section{Örnek:}

Ö5. “Teknolojiden yararlanıyorum. CD’ler, ses filmleri vb. kullanıyorum”.

Ö3. "Bol bol dikte çalışması, metin oluşturma ve okuma çalışmaları ile tekrar yapıyorum".

Ö4. "Basit hikâye kitapları ve piyasada bulunan okuma setleri çok işimize yarıyor. Merkez okulda olduğumdan yayınevleri okula kadar geliyorlar. Kitapları tanıtıyorlar. Bu materyalleri kullanmasak MEB tarafından verilen malzeme ile ilk okuma yazma öğretmek çok zor".

Öğretmenler harf-hece-sözcük ve cümle öğretim sürecine yönelik olarak teknolojiden yararlanma $(n=4)$, sürekli tekrar $(n=13)$ ve ek çalışma materyali kullanma $(n=3)$ şeklinde çözümler ürettiklerini belirtmişlerdir. 
Sayfa/Page | 94 İGÜSBD Cilt: 3 Sayı: 1 Nisan / April 2016

İlk okuma yazma sürecince çocuğa yönelik çözümlerle ilgili öğretmen görüşleri aşağıda tablo 16 'da verilmiștir.

Tablo 16. İlk okuma yazma sürecinde çocukla ilgili çözümlere yönelik öğretmen görüşleri

\begin{tabular}{|c|c|c|}
\hline Tema & Alt Tema & $\mathbf{F}$ \\
\hline \multirow{3}{*}{$\begin{array}{l}\text { Çocuğa } \\
\text { yönelik } \\
\text { çözümler }\end{array}$} & $\begin{array}{l}\text { Aile ile ve rehberlik servisiyle konuşup çözüm } \\
\text { üretme }\end{array}$ & 11 \\
\hline & $\begin{array}{l}\text { Okul öncesi eğitim almak ve okula uyum } \\
\text { eğitimi }\end{array}$ & 3 \\
\hline & $\begin{array}{l}\text { Dikkat çekici ve hatırlamasını kolaylaştırıcı } \\
\text { materyal hazırlama }\end{array}$ & 6 \\
\hline
\end{tabular}

\section{Örnek:}

Ö20. "Aile ile görüşme, bilgilendirme çalışmaları yapıyorum. Gerektiğinde rehberlik servisinden yardım alıyorum. Hep beraber ne yapacağımıza karar veriyoruz".

Ö1. "Dersi teknoloji, şarkı, hikâye ve oyun ile destekleyerek öğrencinin ilgisi toplanıyor. Hatırlaması kolaylaşıyor".

Ö11. "Okula uyum süreci planlanmalı ve okul öncesi yine eskisi gibi zorunlu olmalı”.

Öğretmenlerin ilk okuma yazma sürecinde çocuğa yönelik çözümlerinin aile ve rehberlik servisiyle konuşup çözüm üretme $(n=11)$, okul öncesi eğitimi alma ve okula uyum eğitimi $(n=3)$ ve dikkat çekici ve hatırlamasını kolaylaştırıcı materyal hazırlama $(n=6)$ olarak ifade ettikleri görülmektedir.

İlk okuma yazma sürecince ailelere yönelik çözümlerle ilgili öğretmen görüşleri aşağıda tablo 17 'de verilmiştir.

Tablo 17. İlk okuma yazma süreciyle ilgili olarak ailelerle ilgili çözümlere yönelik öğretmen görüşleri

\begin{tabular}{|l|l|l|}
\hline Tema & Alt Tema & F \\
\hline Ailelere & Aile Eğitimi & 10 \\
\cline { 2 - 3 } Yönelik & Ailelerin okul ile ilişkilerinin & 9 \\
Çözümler & güçlendirilmesi. & \\
\hline
\end{tabular}




\section{Örnek:}

Ö4. "Aile ziyaretleri, bilgilendirme seminerleri hatta aileler için ek dersler yapıyoruz. Öncelikle gelen anneleri (daha çok anneler katılıyor) duygusal ve psikolojik açıdan rahatlatan, huzur ve mutluluk veren videolar izletip onlarla konuşuyorum. Sonra çocuğun okulda öğrendiklerini evde çocuklara nasıl çalıștırmaları gerektiğini anlatıyorum. Birinci sınıfta sık sık veli toplantıları yapıyoruz. Okuma yazma sürecinin mantığını, işleyişini önce velilere öğretiyoruz. İlk okuma yazma sürecinde aileden yardım ve destek almadan öğrencileri eş zamanlı olarak öğrenim sürecine katmak zor. Çünkü her öğrenci aynı hızda öğrenmiyor. Bazılarının daha fazla tekrara ihtiyacı var".

Ö5. "Veli ziyaretleri yapılarak, eğitim-öğretim süreç ile ilgili veli bilgilendirilerek ailenin okulla iletişim kurmasına aracı oluyorum".

Öğretmen görüşleri incelendiğinde ailelere yönelik çözüm aile eğitimi ( $n=10)$ görüşünün ön plana çıktığı, bunu ailelerin okul ile ilişkilerinin güçlendirilmesi $(n=9)$ takip etiği anlaşılmaktadır.

İlk okuma yazma sürecince programla ilgili çözümlere yönelik öğretmen görüşleri aşağıda tablo 18'de verilmiştir.

Tablo 18. Program ve eğitim-öğretim sürecine yönelik çözümlere yönelik öğretmen görüşleri

\begin{tabular}{|l|l|l|}
\hline Tema & Alt Tema & F \\
\hline Programı & Eeliştirme materyal kullanma & 9 \\
\cline { 2 - 3 } & $\begin{array}{l}\text { İlk okuma yazma öğretimi uzun süreye } \\
\text { yayılmalıdır. }\end{array}$ & 11 \\
\hline
\end{tabular}

\section{Örnek:}

Ö12. "Mecburen kaynak kitap aldırmak zorunda kalıyoruz (ilk okuma yazma seti vb.). Kendimiz seslerden oluşan metinler hazırlıyoruz".

Ö11. "Birkaç ayda değil de tüm sene boyunca verilmeli, yani tüm seneye yayılmalı programda seslerin verilmesi ve daha fazla ek alıştırmalar yapılmalı. Program gözden geçirilmeli”.

Sayfa/Page | 95 
Sayfa/Page | 96 İGÜSBD Cilt: 3 Sayı: 1 Nisan $/$ April 2016

Öğretmen görüşleri incelendiğinde program ve eğitim-öğretim sürecine yönelik olarak öğretmenler ek materyal kullanma $(n=9)$ ve ilk okuma yazma öğretim sürecinin zamana yayılması $(n=11)$ şeklinde görüş belirtmişlerdir.

\section{Sonuç ve Öneriler}

Birinci sınıf öğretmenlerinin görüşlerine göre çocukların ilk okuma yazma öğrenmedeki güçlükleri harfleri yazma aşamasında görme örneği olarak harfleri yazma, harflerin yapısında kaynaklı problemler olarak iki temada ele alınmıştır. İlk okuma yazmaya hazırlık ve görme örneği olarak harfleri yazma aşamasında görsel algı bakımından çocukların harflerin mekân ilişkileri (Mekân ilişkileri; mekâna yerleştirme ve şekil-konum-zemin ilişkilerini de kapsar) ve göz-motor koordinasyonu konularında güçlükler yaşadıkları anlaşılmaktadır. Görme örneği olarak harfleri yazmayı öğrenme aşamasında ise harflerin görsel benzerliklerinin ve bağlantı noktalarının öğrenmede problem oluşturduğu görülmektedir. Görme örneği olarak harflerin yazımı aşamasında çocuklar, görsel algı bakımından henüz gelişimlerini tamamlamamışlardır. Çocukların ilk okuma yazmaya hazırlık ve görme örneği olarak harfleri yazma sürecinde zorlanma nedenleri ise okulöncesi eğitimi almamış olmak, hazırbulunuşluk düzeyinin ve motor gelişimin yetersizliği, motivasyon eksikliği, bitişik eğik yazının çocuğa göre olmayışı ve harflerin ilk defa öğreniliyor oluşu olarak belirlenmiştir. Görme algısının gelişimi ilk okuma yazmada etken bir faktördür. Çocukların ilk okuma yazmanın başlangıcında satır kavramına sahip olmadığı, şekil-konum ilişkisi ve mekânda harflerin dizilişi ile ilişkileri konusunda gelişimlerinin henüz tamamlanmadığı söylenebilir.

Birinci sınıf öğrencilerin sesletim bakımından ses öğrenme sürecinde karşılaştıkları güçlükler; bazı seslerin günlük dilde fazla kullanılmaması ( $\breve{\mathrm{g}}, \mathrm{h}, \mathrm{j}$ vb.), bazı sesleri çocukların çıkaramaması ( $r-y$ vb.) ve benzer seslerin ayırt edilememesi (n-m, v-f, b-d-t, s-z, n-l vb.) olarak üç grupta toplanmıştır. Çocukların okuma esnasında benzer harf-sesleri (b-d, n-m vb.), dikte esnasında ise işitilebilirliği düşük ve benzer olan sesleri (n-l, s-z, ğ vb.) karıştırdıkları anlaşılmaktadır. İlk okuma yazmada çocukların sesleri öğrenmelerindeki güçlüklerin ana nedeni ses sayısının artışıyla beraber hatırlanma güçlüguü ve unutma olarak ifade edilmiştir. Birinci sınıf öğrencilerinin ilk okuma yazma esnasında benzer sesleri hem okuma hem diktede karıştırdıkları, seslerin işitilebilirliklerinin ve ayırt ediciliklerinin düşük olduğunda fark edilmelerinin zorlaştığı anlaşılmaktadır. Bazı çocuklar 
ise ses algısı bakımından ilk okuma yazma öğrenebilecek düzeyde gelişimlerini henüz tamamlamamışlardır. Çocuklarda ses algısının gelişimi ilkokul birinci sınıf süresince gelişim göstermektedir. Ses algısının gelişimi de ilk okuma yazma öğrenmede etkili bir faktördür.

İlk okuma yazma öğrenmede öğretmen görüşlerine göre en zor süreç, hece ve sözcük oluşturma sürecidir. Öğretmenler harf-ses bağlantılarını kurup da hece oluşturmaya başlamada öğrencilerinin güçlük çektiklerini vurgulamaktadırlar. Özellikle açık heceleri öğrenmede bu güçlügün arttığı önemle belirtilmektedir. Açı heceyi kavrayan öğrenci, ilk okuma yazmayı da sökmüş olmaktadır. Yine hecelerin ve sözcüklerin uzun oluşu da ilk okuma yazmada önemli bir güçlük noktasıdır. Çocuklar, uzun hece ve sözcükleri okumada pek başarılı değildirler. Harfleri doğru sesletmeyi öğrenmeyen öğrenci, her harfe ses eklemekte veya diktede ünlü harfleri yazmama eğiliminde olabilmektedir. İlk okuma yazma öğretiminde öğretmenler tarafından belirtilen diğer bir güçlük de, harf-ses sayısındaki yetersizlikten dolayı düzgün cümle oluşturmanın zorluğudur. Ortaya çıkan cümlelerin anlamsızlığı, çocuğa göre olmayışı ve kısırlığı süreci olumsuz etkilemektedir. İlk okuma yazma öğretiminde en zor süreç harf-ses çatma denilen aşamadır. Harf-ses çatabilen ve açık heceyi kavrayan çocuklar, ilk okuma yazmayı sökmüş olmaktadır.

İlkokul birinci sınıf öğretmenlerine göre ilk okuma yazma öğretiminde çocuklardan kaynaklanan sebeplerin başında; hazırbulunuşluklarının düşük oluşu, okulöncesi eğitim alınmamış olunması ve yaşının küçüklüğü gelmektedir. Çocukların okuma yazmaya hazırbulunuşluk düzeyleri doğrudan takvim yaşıyla ilişkili değildir. Bazı çocuklar takvim yaşı bakımından büyük olsa da gelişmişlik bakımından daha alt yaşlarda olabilmektedirler. Bu sebeple ilk okuma yazmaya başlangıçta takvim yaşı değil, çocukların gelişmişlik ve hazırbulunuşluk düzeyleri esas alınmalıdır.

İlk okuma yazma sürecinde ailelerin eğitimsiz oluşu ve okula-çocuğa karşı ilgisiz kalmaları eğitim sürecinde büyük bir engel olarak öğretmenlerin karşısına çıkmaktadır. İlkokul birinci sınıf öğretmenlerinin görüşlerine göre programdan kaynaklanan güçlükler ise bitişik eğik yazı ile öğretime başlanması, kazanım sayısının fazla ve yoğun oluşu ile yöntemden dolayı okuyan ama okuduğunu anlamayan bir öğrencinin yetiştiği yönündedir. Öğretmenler, basılı materyalin ise öğretim sürecini desteklemediği ve alıştırmaların yetersiz olduğuna vurgu yapmaktadırlar. İlk okuma yazma öğretiminde yazma sürecine yönelik olarak harf yazım karakterinin çocukların hazırbulunuşluk düzeyine uygun olarak belirlenmesi gerekmektedir. 
Sayfa/Page | 98 İGÜSBD Cilt: 3 Sayı: 1 Nisan / April 2016

İlkokul birinci sınıf öğretmenleri karşılaşılan güçlüklerle baş edebilmek için çeşitli yöntemler geliștirmişlerdir. Görme örneği olarak harfleri yazarken harf öğretim sırasını değiștirme, öğrencinin elinden tutarak yazdırma, tekrara yer verme ve teknolojiden yararlanma gibi değişik çözüm yolları uygulamaktadırlar. Seslerin okunup yazılması sürecinde de yine seslerin sırasını değiştirme, masal-hikâye-tekerleme ve teknolojiden yararlanma ve tekrara yer verme gibi yollara başvurmaktadırlar. Süreç içinde de teknolojiden yararlanma, masal-hikâye ve tekerleme kullanma ve tekrarı sürekli yapma gibi çözümlere öğretmenlerin başvurdukları anlaşılmaktadır. Çocuğa yönelik olarak da elinden tutarak yazdırma, kum masası ve oyun havuzundan yararlanma, dikkat ve ilgi çekici ek materyal tasarlama gibi çözüm yollarını ilk okuma yazmada öğretmenlerin tercih etikleri görülmektedir. İlk okuma yazma öğretim sürecinde teknolojiden azami ölçüde yararlanılması, öğrenme sürecini kolaylaştırıcı bir etki yapmaktadır.

İlkokul birinci sınıf öğretmenlerinin velileri sürekli olarak bilgilendirdikleri ve süreç hakkında eğittikleri de anlaşılmaktadır. Program bakımından ilkokul birinci sınıf öğretmenlerinin görüşlerinde ise dikkat çeken iki tema bulunmaktadır: Bitişik eğik yazı ile öğretimden vazgeçilmesi ve öğretimin uzun döneme yayılması. İlk okuma yazmada ailelerin sürece katkısının önemli olduğu anlaşılmıştır. İlk okuma yazmaya yönelik program geliştirilirken öğretim sürecinin yıl içine yayılmasına özen gösterilmelidir. Bitişik eğik yazı ile öğretime devam etme ısrarcılığından vazgeçilmelidir. Özetle ilk okuma yazma sürecine yönelik bazı öneriler aşağıda verilmiştir:

İlk okuma yazmaya başlayacak çocuklara yönelik hazırbulunuşluk testleri geliştirilmeli ve ilkokula başlamada takvim yaşı değil çocukların hazırbulunuşluğu esas alınmalıdır.

İlk okuma yazma okulöncesi dönemde sürece yönelik hazırlık gerektiren bir öğretimdir. $\mathrm{Bu}$ nedenle çocukların okulöncesi eğitimi almaları desteklenmeli ve okulöncesi programları ilk okuma yazmaya hazırlık bakımından gözden geçirilmelidir.

İlk okuma yazma öğretimindeki harf-ses sırası yeniden düzenlenmelidir. $\mathrm{Bu}$ düzenleme esnasında çocukların benzer ses-harfleri karıştırdıkları göz önüne alınarak benzer-farklı harf-ses eşleştirmeleri yapılarak harf-ses sırası belirlenmelidir.

İlk okuma yazmada harf-ses çatma ve hece-sözcük oluşturma sürecinde alıştırmalar artırılmalıdır. 
Bitişik eğik yazı ile öğretim yerine dik temel harflerle öğretim yapılmalıdır.

İlk okuma yazma öğretiminde ailelerin sürece katkılarının çok fazla olduğu bilinmektedir. Bu nedenle ilk okuma yazma süreci konusunda aileler bilgilendirilmeli ve veli bilgilendirme toplantıları sürekli hale getirilerek aileler sürece etkin olarak katılmalıdır.

\section{KAYNAKÇA}

ACAT, M. Bahattin ve Uğur ÖZSOY, "Ses Temelli Cümle Yöntemiyle İlk Okuma Yazma Öğretiminde Karşılaşılan Güçlükler”, V. Ulusal Sinıf Öğretmenliği Kongresi, Gazi Üniversitesi, Ankara, 2006, ss. 15-37.

ANTHONY J. L. \& J. F. DAVID, "Development of Phonological Awareness", Current Directions in Psychological Science, 14 (5), 2005, ss. 255-259.

BAŞ, Türker ve Ulun AKTURAN, Nitel Araştırma Yöntemleri, Seçkin Yayıncılık, Ankara, 2008.

BINDMAN, S.W., L.E. SKIBBE, A.H. HINDMAN, D. ARAM, F.J. MORRISON, Parental Writing Support and Preschoolers' Early Literacy, Language, and Fine Motor Skills", Early Childhood Research Quarterly, 29 (2014), ss. 614624.

BIRD J., D.V.M. BISHOP, N.H. FREEMAN, Phonological Awareness and Literacy Development in Children With Expressive Phonological Impairments. Journal of Speech, Language, and Hearing Research, Vol. 38, April 1995, ss. 446462.

BLACHMAN, A.B., D.M. TANGEL, E.W.BALL, R. BLACK, C.K. McGRAW, Developing Phonological Awareness and Word Recognition Skills: A TwoYear Intervention with Low-Income, Inner-City Children, Reading and Writing. Volume 11, 1999, Issue 3, ss. 239-273.

BUS, A.G., VAN IJZERDOORN \& H. MARINUS, “Phonological awareness and early reading: A meta-analysis of experimental training studies", Journal of Educational Psychology, Vol 91(3), Sep 1999, ss. 403-414.

CARAVOLAS M. \& M. BRUCK, The Effect of Oral and Written Language Input on Children's Phonological Awareness: A Cross-Linguistic Study, Journal of Experimental Child Psychology, volume 55, Issue 1, February 1993, ss. 1-30.

ÇELENK, Süleyman, Okul Başarısının Ön Koşulu: Okul Aile Dayanışması, İlköğretimonline, 2 (2), 2003, ss. 28-34. http://www.ilkogretim-online.org.tr (Erişim Tarihi: 28.01.2015). 
Sayfa/Page | 100 İGÜSBD Cilt: 3 Sayı: 1 Nisan April 2016

DOIGNON, N \& D. ZAGAR, "Do Children in The Process of Learning to Read Perceive the Syllable in Writing?", Canadian Journal of Experimental Psychology-Revue Canadienne de Psychologie Experimentale, Volume 60, Issue: 4, 2006, ss.258-274.

DUFAU S., LÉTÉ B., TOUZET C., GLOTIN H., ZIEGLER J.C. \& J. GRAINGER, "A Developmantel Perspective on Visual Word Recognition: New Evidence and A Self-Organising Model", European Journal of Cognitive Psychology, Volume 22, Issue 5, 2010, ss 669-694.

FERAH, Aysel, "İlk Okuma-Yazma Döneminde Görsel Algı ve Zekâ İle Okuma-Yazma Arasındaki İlişsilerin Araştırılması", IV. Ulusal Eğitim Bilimleri Kongresi, 1999, ss. 327-341.

FERAH, Aysel, Eylem Boyutuyla İlk Okuma Yazma ve Ezberleme, Milli Eğitim Dergisi, 149, 2001, ss. 22-26.

FERAH, Aysel, Türkçe İlk Okuma ve Yazmayı Öğrenme, Türkçe

Okuyup Yazmak İçin, Ankara, Nobel Yayınları, 2007.

FROSTIG, Marianne, Pictures and Patterns: Teacher's Guide, Palo Alto, CA, Consulting Psychologists Press, 1968.

GRAHAM S.; STRUCK M.; SANTARO J. \& V. W. BERNINGER, “Dimensions of Good and Poor Handwriting Legibility in First and Second Graders: Motor Programs, Visual-Spatial Arrangement, and Letter Formation Parameter Setting", Developmental Neuropsychology, Vol. 29 (1), 2010, ss. 43-60.

KIRSTEN L. WINDFUHR \& MARGARET J. SNOWLING, "The Relationship between Paired Associate Learning and Phonological Skills in Normally Developing Readers", Journal of Experimental Child Psychology, Volume 80, Issue 2, October 2001, ss. 160-173.

LONIGAN, C. J.; BURGESS, S.R.; ANTHONY, J. L. \& T. A. BARKER, Development of phonological sensitivity in 2- to 5-year-old children, Journal of Educational Psychology, Vol 90 (2), Jun 1998, ss. 294-311.

MERRIAM, S.B., Nitel Araştırma, (çev. ed. S. Turan), Nobel Yayıncılık, Ankara, 2013.

MILES, M.B \& A.M. HUBERMAN, Qualitative Data Analysis: An

Expanded Sourcebook, (2nd Edition), SAGE Publications, Calif, 1994.

SCHUNK, D.H., Öğrenme Teorileri, (çev. M. Y. Demir... vd.), Nobel Yayıncllık, Ankara, 2009.

SIMNER, M.L., "Printing Erors in Kindergarten and the Prediction of Akademic Performance”, Journal of Learning Disabilities, 15 (1), 1982, ss. 155160. 
ŞAHINEL, M. G., M. KARASU, “Türkçe 1-5. Sınıflar Öğretim Programı İlk Okuma-Yazma Öğretimine İlişkin Öğretmen Görüşleri”, VI. Ulusal Sinıf Öğretmenliği Eğitimi Sempozyumu, Nobel Yayıncılık, Ankara, 2007, ss. 233238.

ÖZYÜREK, A. ve E. ÖMEROĞLU,“Bellek Eğitimi Programının Altı Yaşındaki Çocukların Bellek Gelişimine Etkisinin İncelenmesi”, Eğitim ve Bilim, 38 (168), 2013, ss. 30-45.

ÖZCAN, A. O., "İlk Okuma Yazma Döneminde Yazma Becerisini Öğrenme”, Marmara Üniversitesi Atatürk Ĕgitim Fakültesi Eğitim Bilimleri Dergisi, 3, 1991, ss. 203-207.

ÖZCAN, A. O., "Illk Okuma Yazma Öğretim Programlarının Geliştirilmesi", Hacettepe Üniversitesi Eğitim Bilimleri Dergisi, 8, 1992, ss. 167-178.

ÖZCAN, A. O., "İlk Okuma Yazma Öğretiminde Rol Oynayan Psikolojik Faktörler”, Hacettepe Üniversitesi II. Eğitim Bilimleri Sempozyumu Bildirileri, 1995, ss. 3-9.

ÖZCAN, A. O. \& A. FERAH ÖZCAN, Türk Çocuklarının Ses Gelişim Özellikleri ve İlk Okuma Yazma Öğrenme, İstanbul Gelişim Üniversitesi Sosyal Bilimler Dergisi, 1 (2), 2014, ss. 67-86.

TRAWICK-SWITH , J., Erken Çocukluk Döneminde Gelişim, (çev. ed. Berrin Akman), Ankara, Nobel Yayınları, 2013.

WAGNER, R. K.; TORGESEN, J. K. \& C. A. RASHOTTE, “Development $\mathrm{f}$ Reading-Related Phonological Processing Abilities: New Evidence of Bidirectional Causality From A Latent Variable Longitudinal Study", Developmental Psychology, 30 (1), 1994, ss. 73-87.

WHITE, K.M., "Associations Between Teacher-Child Relationships and Children's Writing in Kindergarten and First Grade", Early Childhood Research Quarterly, 28, 2013, ss. 166-176.

WINDFUHR, K.L. \& M.J. SNOWLING, "The Relationship Between Paired Associate Learning and Phonological Skills in Normally Developing Readers", Journal of Experimental Child Psychology, 80 (2), 2001, ss. 160-173.

VERNON, S.A. \& EMILIA FERREIRO, Writing Development: A Neglected Variable in the Consideration of Phonological Awareness, Harvard Educational Review, 0017-8055 (Print) 1943-5045 (Online), Volume 69, Number 4 / Winter 1999, ss 395-416. 
Sayfa/Page | 102 İGÜSBD Cilt: 3 Sayı: 1 Nisan $/$ April 2016

\section{Summary}

Turkish initial reading-writing with Turkish alphabet learning does not mean the same reality. The child must have access to a certain level of development and maturity to be able to start learning Turkish alphabet. In this case, school readiness or maturity, type and so on. It is expressed in the concept. Readiness; perceptual development, cognitive development, physical maturity and so on, it makes reference to qualifications.

Turkish alphabet to learn a second requirement is the development of awareness and recollection functions of the language units. If what you're taught teaching method to write the first reading, the above skills, skills that are essential to learn the Turkish alphabet. Initial literacy process of the execution as planned other items such as teachers and parents involved in the learning environment is also important. Awareness of and commitment to the child's learning process with parents supporting research activities that contributed to the child's learning to write in initial reading has been demonstrated.

In this study, initial literacy learning in children's language unitary awareness and qualitative multidimensional data analysis with the difficulties they encounter when learning to write the initial reading of children and solutions after the additives discussed as long as the family relationship of the memory function is determined. The research was conducted with twenty primary school teachers who teach the first class. In reference to the views of participants in the process itself, qualitative / phenomenon science methods with the case in accordance with the form of semi-structured interviews were collected. The data collected, the theme and sub-themes have been identified and tabulated for frequency calculation is made of the descriptive statistics.

The aim of the research, without falling into the methods concern is to put children first appeared literacy learning difficulties encountered and the solutions. At research result; initial reading-writing, writing letters, voice training, difficulties in language analysis units, child and family-induced difficulties, challenges and solutions induced programs and printed material have been determined on the basis of teachers' opinions. As a result, the process of writing the letters of the alphabet children's perception of spatial relationships were found to have difficulty in the process of writing the letters and eye-motor coordination dimension. Difficulties related to the process of 
writing letters missing children consisting of readiness is related to variables such not receive pre-school education.

Findings that emerged in the study, children's similar voices of pronunciation and had difficulty in writing similar letters are interesting. This finding is consistent with the literature on visual perception. Because, according to the literature, children having more difficulty on detection of similar objects than different objects. The possibility of mixing of similar letter-sound is high.. Especially open syllables to reach; it is very difficult action for children. Children's language unit in the very long words and syllables have difficulty in reading, they tend to forget the vowels of dictates are among the findings of the investigation. At initial reading, most difficult process of children in writing is the process of letter-sound collisions. In this case, "Initial read and write, What if you learned learning method, when they start to frown children letter-sound is solved" our thesis is confirmed.

According to the teachers' opinions, the initial literacy education must be dispensed from teaching and writing with italic handwriting on initial reading should be spread for a long time, the judiciary has come to the fore. This result is quite striking. Initial literacy education is not provided in cases of short compressed and family support; and activities of teaching writing is becoming a difficulty in initial reading. Based on the research findings of the review as teaching letter-sound, vision and awareness-raising actions of sound reorganization of the activities and children etc. to determine the initial literacy readiness, there have been a number of suggestions. Research is instructive way as all those who are interested in assessing the initial literacy learning process area.

Sayfa/Page | 103

İGÜSBD

Cilt: 3 Sayı: 1

Nisan /

April 2016 